\title{
The role of $\mathrm{His}^{66}$ and $\mathrm{His}^{72}$ in the reaction mechanism of bovine liver low- $M_{\mathrm{r}}$ phosphotyrosine protein phosphatase
}

\author{
Paola CHIARUGI, Paolo CIRRI, Guido CAMICI, Giampaolo MANA0, Tania FIASCHI, Giovanni RAUGEI, Gianni CAPPUGI \\ and Giampietro RAMPONI* \\ Dipartimento di Scienze Biochimiche, Universita' di Firenze, Viale Morgagni 50, 50134 Firenze, Italy
}

Site-directed mutagenesis of a synthetic gene coding for low- $M_{\mathrm{r}}$ phosphotyrosine protein phosphatase from bovine liver has been carried out. The two histidine residues in the enzyme have been mutated to glutamine; both single and double mutants were produced. The mutated and non-mutated sequences have been expressed in Escherichia coli as fusion proteins, in which the low$M_{\mathrm{r}}$ phosphotyrosine protein phosphatase was linked to the Cterminal end of the maltose-binding protein. The fusion enzymes were easily purified by single-step affinity chromatography. The mutants were studied for their kinetic properties. Both single mutants showed decreased $k_{\text {eat. }}$ values (30 and 7\% residual activities for $\mathrm{His}^{66}$ and $\mathrm{His}^{72}$ respectively), and alterations of the $K_{1}$ values relative to four competitive inhibitors were observed. The kinetic mechanism of $p$-nitrophenyl phosphate hydrolysis in the presence of both single mutants was determined and compared with that of the non-mutated enzyme. The rate-determining step of the catalytic process of the $\mathrm{His}^{66} \rightarrow \mathrm{Gln}$ mutant was the same as that found for non-mutated enzyme, whereas for the $\mathrm{His}^{72} \rightarrow$ Gln mutant, both the kinetic constant of the step that causes the formation of a phosphoenzyme covalent intermediate, and the kinetic constant of the step that causes the dephosphorylation of the enzyme covalent intermediate, determined the $k_{\text {cat. }}$ value. This observation was confirmed by phosphoenzyme covalent intermediate trapping experiments. The participation of both histidine residues ( $\mathrm{His}^{66}$ and $\mathrm{His}^{72}$ ) at the active site is strongly suggested by the results of diethyl pyrocarbonate inactivation of both single mutants, each containing a single histidine residue. Both mutants are completely inactivated by diethyl pyrocarbonate treatment; the competitive inhibitor $P_{1}$ protects both mutants from inactivation. The $\mathrm{His}^{66} / \mathrm{His}^{72}$ double mutant was completely inactive.

\section{INTRODUCTION}

Protein tyrosine phosphorylation is an important means by which cells control their growth rate. Both phosphotyrosine protein kinases and phosphotyrosine protein phosphatases (PTPases) are involved in the maintenance of the homeostatic balance required for tyrosine-phosphorylation-mediated signalling. Several phosphotyrosine protein kinases are intracellular domains of growth factor receptors; that both their activity and substrate specificity are altered in the presence of the specific growth factor confirms their important role in growth factor signal transduction. On the other hand, the function of the intracellular ( $s r c$ gene-like) phosphotyrosine protein kinases is not well understood. PTPases comprise a multigene family and divide into intracellular and transmembrane receptor-like proteins [1-3]. Many oncogene products are distorted elements of the growth factor message transduction system, and cells expressing these oncogenes generally enhance their growth rate and behave like cancer cells. PTPases oppose the action of these oncogenes, probably by dephosphorylating the Tyrphosphorylated growth factor intracellular domains and other Tyr-phosphorylated protein substrates.

Bovine liver contains a low- $M_{\mathrm{r}}$ PTPase (EC 3.1.3.48) which was previously known as low- $M_{\mathrm{r}}$ acid phosphatase (EC 3.1.3.2). This enzyme was first sequenced in our laboratory [4]. We demonstrated that the enzyme is able to dephosphorylate in vitro the Tyr-autophosphorylated epidermal growth factor receptor, but it is not able to dephosphorylate casein phosphorylated by the cyclic AMP-dependent protein kinase [5]. Vanadate (an inhibitor of all PTPase family members) strongly inhibits this particular enzyme [6]. Similar enzymes have been purified from other tissues, and some authors have demonstrated that their activity is specific for Tyr-phosphorylated proteins [7-10]. We have recently constructed a synthetic gene that codes for low- $M_{r}$ PTPase. This gene has been expressed in Escherichia coli as an active enzyme [11]. This construct was also transfected into normal and oncogene-transformed cells. We studied the effect of enzyme overexpression in these systems and found that it is accompanied by a decrease in thymidine incorporation and a decrease in cell growth rate both in normal and in soft agar [12]

Low- $M_{\mathrm{r}}$ PTPase isoenzyme pairs have been purified and completely sequenced from both rat liver and human erythrocytes [13-15]. In both species, the isoenzymes differ only for residues $40-73$, where an alternative sequence is found. They probably originated from a single gene by an alternative splicing mechanism.

The reaction mechanism of the enzyme has been studied extensively and it is known that a transient thiol-phosphate covalent intermediate is formed during the catalytic process [16-20]. All low- $M_{\mathrm{r}}$ PTPase isoenzymes from rat liver and human erythrocytes, as well as that from bovine liver, contain

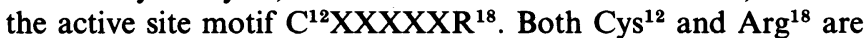
essential for catalysis [17,21]. A similar motif is present in the active site of all PTPase family members [17]; nevertheless, the enzyme has no general homology with the receptor-like PTPases [i.e. leucocyte-antigen-related PTPase (LAR) and leucocyte

Abbreviations used: PTPase, phosphotyrosine protein phosphatase; CD45, leucocyte common-antigen PTPase; LAR, leucocyte-antigen-related PTPase; PTP 1B, human placental PTPase; DEP, diethyl pyrocarbonate; MBP, maltose-binding protein.

* To whom correspondence should be addressed. 
common-antigen PTPase (CD45)] and non-receptor-like PTPases [i.e. human placental PTPase (PTPase 1B)], suggesting that it is distantly related to the main PTPase family members.

The present paper deals with the participation of both $\mathrm{His}^{66}$ and $\mathrm{His}^{72}$ in the reaction mechanism of bovine liver low- $M_{r}$ PTPase.

\section{MATERIALS AND METHODS}

\section{Materials}

L-Phosphotyrosine, $p$-nitrophenyl phosphate, phenyl phosphate, 2-naphthyl phosphate and diethyl pyrocarbonate (DEP) were purchased from Sigma. pMALc vector, amylose resin and $E$. coli strain TB1 were obtained from New England Biolabs. Stu 1 and HindIII restriction enzymes, T4 DNA ligase and Taq DNA polymerase were obtained from Promega. Sequenase was obtained from USBC. $\left[{ }^{32} \mathrm{P}\right] \mathrm{P}_{1}(8500 \mathrm{Ci} / \mathrm{mmol})$ and $\left[\alpha^{-32} \mathrm{P}\right] \mathrm{ATP}$ $(3000 \mathrm{Ci} / \mathrm{mmol})$ were obtained from NEN. Benzoyl $\left[{ }^{32} \mathrm{P}\right]-$ phosphate was synthesized as previously described [17].

\section{Enzyme assay and kinetic parameters}

Enzyme activity on $p$-nitrophenyl phosphate was determined by following $p$-nitrophenol release at $37^{\circ} \mathrm{C}$ and $\mathrm{pH} 5.5$ from $p$ nitrophenyl phosphate $\left(\epsilon_{400}=18000 \mathrm{M}^{-1} \cdot \mathrm{cm}^{-1}\right)$ in alkaline solution. In the experiments related to the determination of $K_{\mathrm{s}}$ (the true enzyme-substrate dissociation constant), the $\mathrm{P}_{1}$ release was followed using the method of Baginski [22]. $K_{\mathrm{m}}$ and $V_{\max }$. were determined by measuring the initial substrate hydrolysis rate in

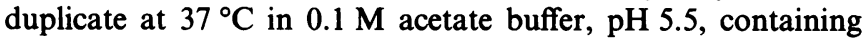
$1 \mathrm{mM}$ EDTA, and then by plotting the reciprocal of the initial rates measured at varying substrate concentrations versus the reciprocal of the initial substrate concentrations, according to Lineweaver and Burk [23].

\section{Doterminations of $\boldsymbol{K}_{3}, \boldsymbol{K}_{+2}$ and $\boldsymbol{K}_{+3}$ for His $\rightarrow$ Gin and His $\mathrm{Hz}^{\mathrm{ED}} \rightarrow \mathrm{Gln}$ mutants}

The true enzyme-substrate dissociation constants $\left(K_{\mathrm{s}}\right)$ for the non-mutated and mutated enzymes were determined employing the method described by Zhang and Van Etten for the closely related low- $M_{\mathrm{r}}$ PTPase from bovine heart [18]. This method is based on the transphosphorylation properties of the enzyme. In fact, when the enzymic reaction is carried out in the presence of a phosphate acceptor, there is a partitioning between water and the acceptor, as shown in Scheme 1:

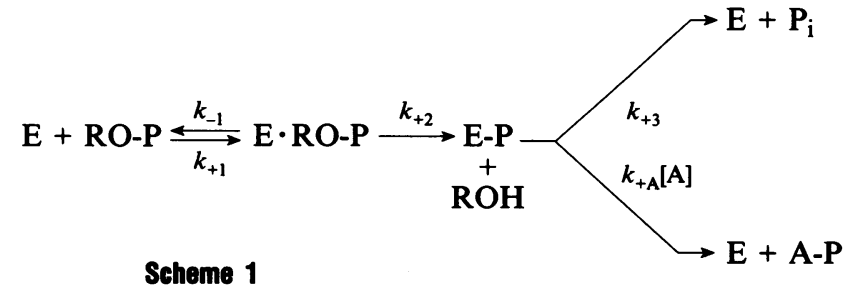

where E represents enzyme, RO-P p-nitrophenyl phosphate, E. RO-P Michaelis complex, E-P phosphoenzyme covalent intermediate, $\mathrm{ROH} p$-nitrophenol, $\mathrm{A}$ the acceptor molecule (in our case glycerol) and A-P phosphorylated acceptor.
The hydrolysis of $p$-nitrophenyl phosphate was carried out in the presence of increasing concentrations of glycerol $(0-1 \mathrm{M})$, and the following equation was used to calculate $K_{\mathrm{s}}$ (see Zhang and Van Etten [18]):

$$
\frac{[\mathrm{E}]_{0}}{v_{0}\left(\mathrm{P}_{1}\right)}=\frac{k_{+2}+k_{+3}+k_{+\mathrm{A}}[\mathrm{A}]}{k_{+2} k_{+3}}+\frac{K_{\mathrm{s}}\left(k_{+3}+k_{+\mathrm{A}}[\mathrm{A}]\right)}{k_{+2} k_{+3}} \cdot \frac{1}{[\mathrm{~S}]}
$$

$[\mathrm{E}]_{0}$ is the total enzyme concentration, $v_{0}\left(\mathrm{P}_{\mathrm{i}}\right)$ is the initial rate of $P_{1}$ release from the substrate (S), $A$ is the acceptor molecule (glycerol, in our case) used in the partition experiments, and $K_{\mathrm{s}}=k_{-1} / k_{+1}$. A plot of $[\mathrm{E}]_{0} / v_{0}\left(\mathrm{P}_{1}\right)$ versus $1 /[\mathrm{S}]_{0}$ gave a series of straight lines corresponding to the different glycerol concentrations. These lines intersect at a common point in the upper left quadrant at which the abscissa $1 /[\mathrm{S}]_{0}=-1 / K_{\mathrm{s}}$.

\section{Site-directed mutagenesis}

The $\mathrm{His}^{66} \rightarrow \mathrm{Gln}$ and $\mathrm{His}^{72} \rightarrow \mathrm{Gln}$ mutants and the $\mathrm{His}^{66}$. $\mathrm{His}^{72} \rightarrow$ Gln double mutant were all obtained by site-directed mutagenesis of a synthetic gene coding for low- $M_{\mathrm{r}}$ PTPase [11] using the procedure described by Mullis et al. [24]. The mutated sequences were cloned into the StuI/HindIII single restriction sites of the pMALc vector and the recombinant clones were analysed by hybridization and DNA sequencing. The nonmutated and mutated enzymes were expressed in $E$. coli as fusion proteins, where the PTPase sequences are linked at the Cterminus of the maltose-binding protein (MBP). Recombinant PTPase fusion proteins were purified by affinity chromatography as previously described [21]. The recombinant non-mutated fusion protein retains most of its original activity and affinity versus substrates and inhibitors, as we have previously demonstrated, making them suitable for functional studies [17].

\section{Phosphoenzyme covalent Intermediate trapping experiments}

Phosphoenzyme covalent intermediate trapping experiments were performed with both $\mathrm{His}^{66}$ and $\mathrm{His}^{72}$ mutants using the procedure previously described [17]. This technique, first described by Guan and Dixon [25] for rat PTP1 and by Pot et al. [26] for LAR, is based on the incubation of a large excess of ${ }^{32} \mathrm{P}$ labelled substrate with the enzyme for only a few seconds, followed by a rapid denaturation caused by the addition of an SDS solution. Under these experimental conditions, the phosphoenzyme trapping yield depends mainly on the relative rates of denaturation and of phosphoenzyme dephosphorylation during the denaturation process. This procedure gives a low but reproducible yield of phosphoenzyme and therefore has been previously used to study the effect of site-directed mutation on the step that leads to the dephosphorylation of the enzyme (see the results for the $\mathrm{Cys}^{17} \rightarrow$ Ser mutant in [17]).

\section{Chemical modfication of histidine with DEP}

Chemical modification of histidine with DEP was performed by incubating non-mutated and mutated recombinant PTPases fusion proteins $(1 \mathrm{nmol})$ dissolved in $100 \mu \mathrm{l}$ of $0.15 \mathrm{M} \mathrm{3,3-}$ dimethylglutarate buffer, $\mathrm{pH} 6.5$, with DEP $(2 \mathrm{mM})$ in both the absence and presence of $30 \mathrm{mM} \mathrm{P}$ (a competitive inhibitor). The mixtures were incubated at $25^{\circ} \mathrm{C}$ and the inactivation was monitored by measuring the remaining activity after various incubation periods. 


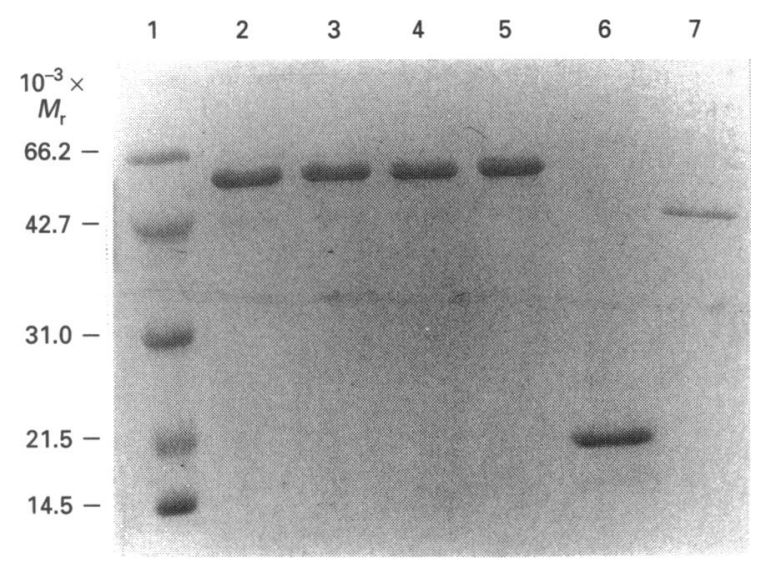

Figure 1 SDS/PAGE of natural and recombinant proteins

Lane 1, standard proteins; lane 2, non-mutated MBP-PTPase fusion protein; lane 3, MBPPTPase $\mathrm{His}^{66} \rightarrow \mathrm{Gln}$ mutant; lane 4, MBP-PTPase $\mathrm{His}^{72} \rightarrow \mathrm{Gln}$ mutant; lane 5, $\mathrm{His}^{66}$ - $\mathrm{His}^{72} \rightarrow \mathrm{Gln}$ double mutant; lane 6, natural low- $M_{\mathrm{r}}$ PTPase; lane 7, MBP. $M_{\mathrm{r}}$ markers are shown on the left.

\section{RESULTS AND DISCUSSION}

\section{Effect of sitte-directed mutagenesis of $\mathrm{His}^{\mathrm{es}}$ and $\mathrm{His}^{72}$ on the catalytic process}

Figure 1 shows the SDS/PAGE analysis of the recombinant non-mutated and mutated PTPase fusion proteins purified from $E$. coli extract. It can be seen that a single protein with an $M_{\mathrm{r}} \sim 60000$ is present in lanes $2-5$, which correspond to nonmutated, $\mathrm{His}^{66} \rightarrow \mathrm{Gln}$ mutated, $\mathrm{His}^{22} \rightarrow \mathrm{Gln}$ mutated, and $\mathrm{His}^{68} / \mathrm{His}^{72}$ double mutated PTPase fusion proteins, respectively. Considering that natural PTPase has an $M_{\mathrm{r}}$ of 18000 (lane 6) and that the MBP has an $M_{\mathrm{r}}$ of $\mathbf{4 2 0 0 0}$ (lane 7), all four recombinant fusion proteins have molecular mass values consistent with the sum of the molecular mass of MBP and the natural enzyme.

MBP-fusion enzymes were used in all kinetic experiments, as we had previously demonstrated that the non-mutated fusion enzyme retains almost the same kinetic properties as natural low$M_{\mathrm{r}}$ PTPase [17]. Table 1 shows the $k_{\text {cat }}$ values for $p$-nitrophenyl phosphate hydrolysis (measured at $37^{\circ} \mathrm{C}$ ) of all His mutants and that of the non-mutated enzyme. Losses of $70 \%$ activity for $\mathrm{His}^{66} \rightarrow \mathrm{Gln}$ and of $93 \%$ activity for $\mathrm{His}^{72} \rightarrow \mathrm{Gln}$ mutants were found. On the other hand, the $\mathrm{His}^{66}-\mathrm{His}^{22} \rightarrow \mathrm{Gln}$ double mutant is completely inactive. These data suggest that both histidine residues are involved in the active site. These findings seem to contrast with those of Zhang et al. [19], who suggested the involvement of a single histidine residue in the active site of the bovine heart enzyme (which is structurally identical to that of bovine liver).

In a previous paper, we demonstrated that pyridoxal $5^{\prime}$ phosphate and its analogues pyridoxal and pyridoxamine $5^{\prime}$ phosphate act as competitive inhibitors of low- $M_{\mathrm{r}}$ PTPase, although with very different affinities [27]. We proposed that pyridoxal 5'-phosphate interacts with the enzyme active site at two points, one involving the phosphate moiety and the other involving the aldehyde moiety of pyridoxal 5'-phosphate. In the present study, we determined the inhibition type and the inhibition constants for pyridoxal 5'-phosphate, pyridoxamine 5'phosphate, pyridoxal and $\mathrm{P}_{1}$ towards the $\mathrm{His}^{68}$ and $\mathrm{His}^{72}$ mutated fusion proteins and towards the non-mutated recombinant enzyme. In addition, the $K_{\mathrm{m}}$ values of mutated and non-mutated enzymes were compared.

Figure 2, Figure 3 and Table 1 show the results obtained. It can be seen that all inhibitors behave competitively, as they do for the non-mutated recombinant enzyme; however, some differences in the $K_{\mathrm{m}}$ and $K_{1}$ values with respect to the non-mutated enzyme were observed. In fact, in the case of the $\mathrm{His}^{66} \rightarrow \mathrm{Gln}$ mutant, we found that, relative to the non-mutated enzyme, the $K_{\mathrm{t}}$ values for $\mathrm{P}_{\mathrm{i}}$ increased eight times, and those for pyridoxal 5'phosphate and pyridoxamine 5 -phosphate increased about four times, whereas the value for pyridoxal remained very close to that of the non-mutated enzyme. These findings suggest that the replacement of $\mathrm{His}^{66}$ with Gln decreases the binding of three out of four of the tested inhibitors, as replacement is accompanied by increased dissociation constants for these inhibitors. In the case of the $\mathrm{His}^{72} \rightarrow \mathrm{Gln}$ mutant, our results are similar to those obtained for the $\mathrm{His}^{66} \rightarrow \mathrm{Gln}$ mutant. In the latter case, the ability of the mutant to interact with the inhibitors appears to be further decreased, as all $K_{1}$ values were higher than those found for the $\mathrm{His}^{6 \mathrm{6}} \rightarrow$ Gln mutant. Moreover, the $K_{1}$ for pyridoxal was about three times higher than that found for the non-mutated enzyme.

$K_{\mathrm{s}}$ (the true equilibrium dissociation constant) was determined as described in the Materials and methods section. The plots that were used for $K_{\mathrm{s}}$ determination are shown in Figure 4. Applying the steady-state assumption to [E-P] (Scheme 1), $K_{\mathrm{m}}=K_{\mathrm{s}} k_{+3} /\left(k_{+2}+k_{+3}\right)$ and $k_{\text {cat. }}=k_{+2} k_{+3} /\left(k_{+2}+k_{+3}\right)$ (see [18]). $k_{+2}$ and $k_{+3}$ values for the non-mutated and mutated enzymes were calculated from the last two equations using the appropriate $k_{\text {cat. }}$ and $K_{\mathrm{m}}$ values. All these $K_{\mathrm{m}}, K_{\mathrm{s}}, k_{+2}$ and $k_{+3}$ values are summarized in Table 1.

With reference to Scheme 1 and Table 1, we can observe that both $\mathrm{His}^{68} \rightarrow \mathrm{Gln}$ and $\mathrm{His}^{72} \rightarrow \mathrm{Gln}$ mutants display values of $k_{+2}$ and $k_{+3}$ lower than those for the non-mutated enzyme. This indicates that the $\mathrm{His}^{66}$ or $\mathrm{His}^{72}$ mutations cause a perturbation of both the E-P formation and hydrolysis steps. Nevertheless,

\section{Table 1 Summary of some kinetic parameters determined for non-mutated and histidine-mutated MBP-PTPases}

All measurements were carried out at $37^{\circ} \mathrm{C}$ and $\mathrm{pH} 5.5$. The substrate $p$-nitrophenyl phosphate has been used for determining all $K_{\mathrm{m}}, K_{\mathrm{s}}, k_{+2}, k_{+3}, k_{\text {cat }}$ and $K_{\mathrm{i}}$ values. Inhibition was competitive for all tested compounds (PLP, pyridoxal 5'-phosphate; PAMP, pyridoxamine 5'-phosphate; PAL, pyridoxal; $P_{\mathrm{i}}$, inorganic phosphate).

\begin{tabular}{|c|c|c|c|c|c|c|c|c|c|}
\hline \multirow[b]{2}{*}{ Mutant } & \multirow{2}{*}{$k_{\text {cat }}$} & \multirow{2}{*}{$\begin{array}{l}K_{\mathrm{m}} \\
(\mathrm{mM})\end{array}$} & \multirow{2}{*}{$\begin{array}{l}K_{\mathrm{s}} \\
(\mathrm{mM})\end{array}$} & \multirow{2}{*}{$\begin{array}{l}k_{+2} \\
\left(s^{-1}\right)\end{array}$} & \multirow{2}{*}{$\begin{array}{l}k_{+3} \\
\left(s^{-1}\right)\end{array}$} & \multicolumn{4}{|c|}{$K_{\mathrm{i}}(\mathrm{mM})$} \\
\hline & & & & & & PLP & PAMP & PAL & $P_{i}$ \\
\hline Native & 29 & 0.45 & 6.0 & 384 & 31.1 & 0.013 & 6.0 & 12 & 1.0 \\
\hline $\mathrm{His}^{66} \rightarrow \mathrm{Gln}$ & 8.5 & 1.78 & 12.2 & 58.2 & 9.9 & 0.050 & 28 & 15 & 8.0 \\
\hline $\mathrm{His}^{72} \rightarrow \mathrm{Gln}$ & 2.0 & 4.30 & 14.5 & 6.70 & 2.8 & 0.085 & 39 & 39 & 15 \\
\hline $\begin{array}{c}\mathrm{His}^{66} \cdot \mathrm{His}^{72} \rightarrow \mathrm{Gln} \\
\text { double mutant }\end{array}$ & 0 & - & - & - & - & - & - & - & - \\
\hline
\end{tabular}



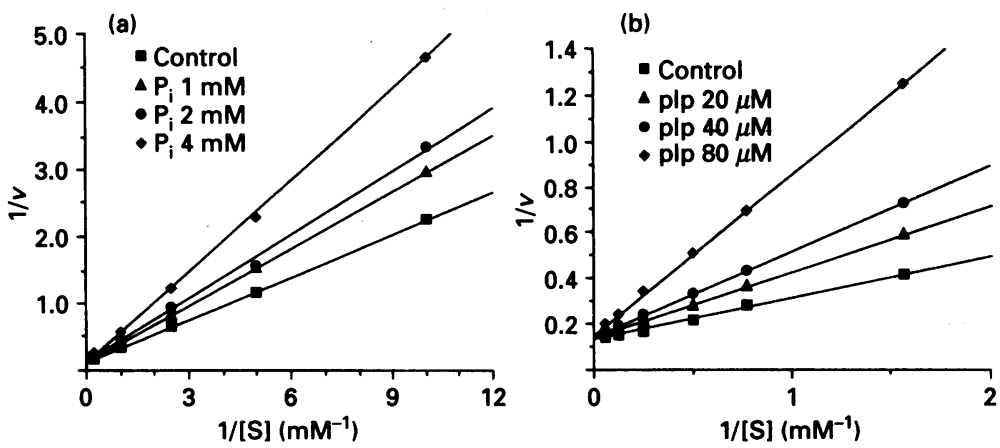

(c)
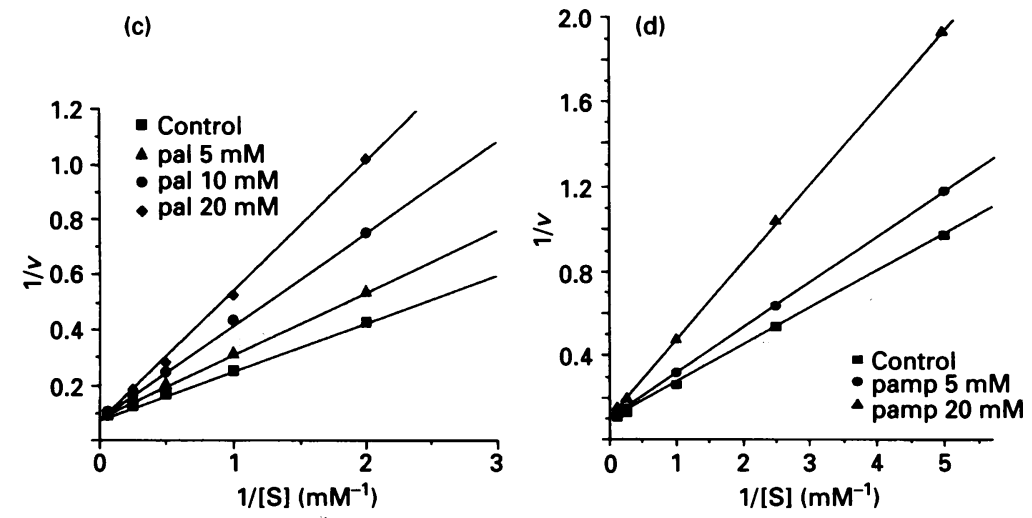

Figure 2 Inhibition of the low-M, MBP.PTPase Hises $\rightarrow$ Gin mutant by $P_{1}$, pyridoxal 5'-phosphate and pyridoxal 5'-phosphate analogues (Lineweaver-Burk plots)

(a) $\mathrm{P}_{\mathrm{i}}$ inhibition; (b) pyridoxal 5'-phosphate (plp) inhibition; (c) pyridoxal (pal) inhibition; (d) pyridoxamine $5^{\prime}$-phosphate (pamp) inhibition. The initial rates were measured at $37{ }^{\circ} \mathrm{C}$ and $\mathrm{pH} 5.5$, using p-nitrophenyl phosphate as substrate. The inhibitor concentrations are indicated. Control indicates experiments performed without the inhibitors. $1 / \mathrm{v}$ is expressed as $\mu$ mol ${ }^{-1} \cdot \mathrm{min}^{\cdot} \cdot \mathrm{ml}$.
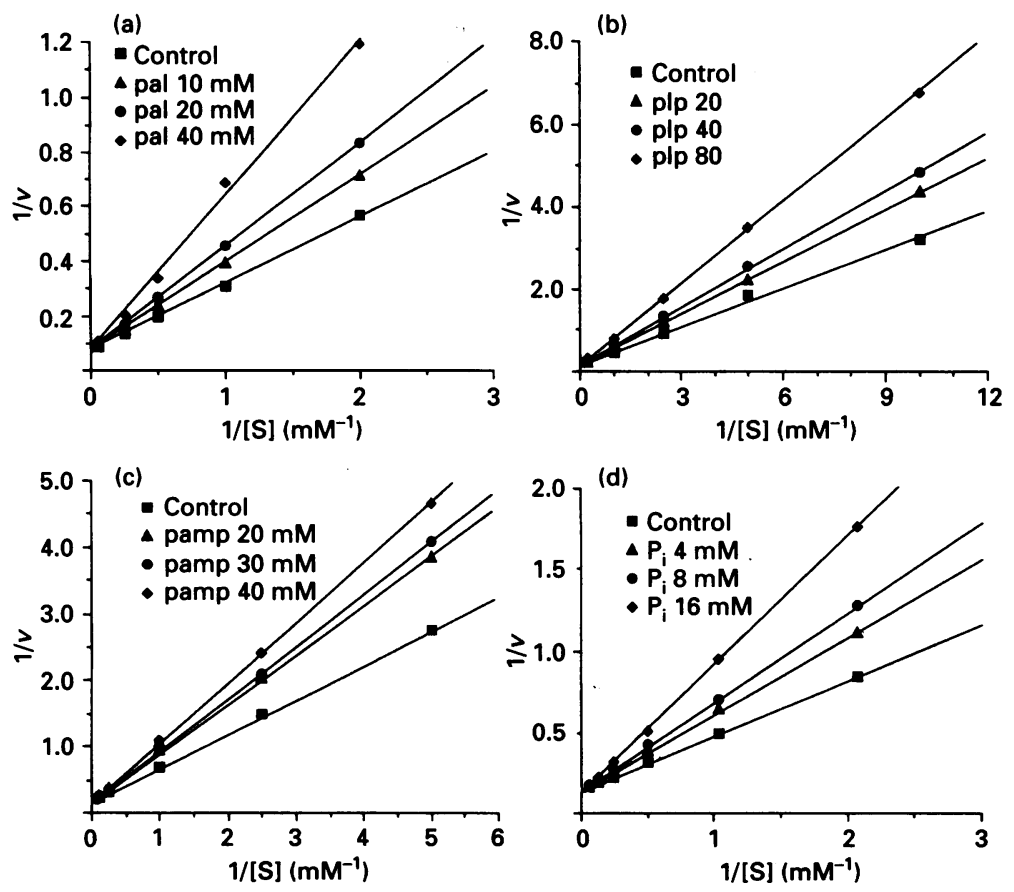

Figure 3 Inhibttion of the low-M, MBP-PTPase His $\rightarrow$ Gin mutant by $P_{p}$ pyridoxal 5'-phosphate and pyridoxal 5'-phosphate analogues (Lineweaver-Burk plots)

(a) Pyridoxal (pal) inhibition; (b) pyridoxal $5^{\prime}$-phosphate (plp) inhibition; (c) pyridoxamine $5^{\prime}$-phosphate (pamp) inhibition; (d) $P_{j}$ inhibition. The initial rates. were measured at $37{ }^{\circ} \mathrm{C}$ and pH 5.5 , using p-nitrophenyl phosphate as substrate. The inhibitor concentrations are indicated. Control indicates experiments performed without the inhibitors. $1 / \mathrm{v}$ is expressed as $\mu$ mol ${ }^{-1} \cdot \mathrm{min} \cdot \mathrm{ml}$. 

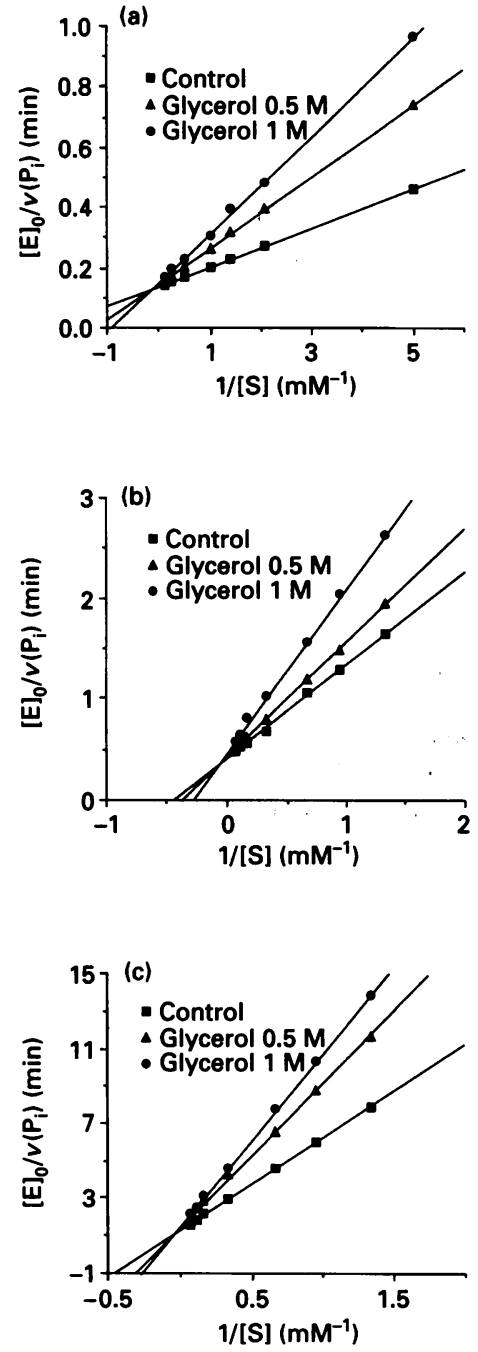

Figure 4 Plot of $[E], / v_{0}(P)$ versus $1 /[S]$, for the determinations of the true enzymo-substrate dissociation constants $\left(K_{2}\right)$ for p-nitrophenyl phosphate relattve to the non-mutated and mutated low- $M$, MBP-PTPases

The experiments were performed at $37^{\circ} \mathrm{C}$ and $\mathrm{pH} 5.5$. At the intersection point, $1 /[\mathrm{S}]_{0}=$ $-1 / K_{\mathrm{s}}$. (a) Non-mutated MBP-PTPase; (b) $\mathrm{His}^{66} \rightarrow \mathrm{Gin}$ mutant; (c) His ${ }^{72} \rightarrow$ Gin mutant. Control indicates experiments performed without glycerol.

2

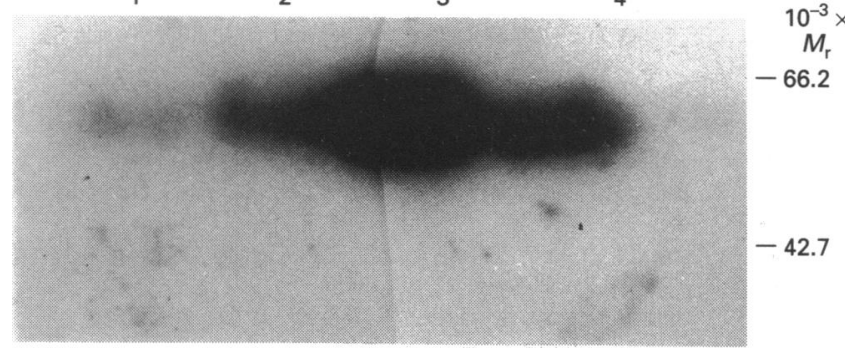

Figure 5 Phosphoenzyme covalent intermedlate trapping

Enzymes were incubated with benzoyl: $\left.{ }^{32} \mathrm{P}\right]$ phosphate for a few seconds, and the phosphoenzyme was trapped by rapid mixing with an SDS solution [17]. Then the samples were directly applied to polyacrylamide wells. Lane 1, MBP-PTPase $\mathrm{His}^{72} \rightarrow \mathrm{Gln}$ mutant; lane 2, MBP-PTPase $\mathrm{His}^{66} \rightarrow$ Gln mutant; lane 3; Cys ${ }^{17} \rightarrow$ Ser mutant [13]; lane 4, non-mutated MBP-PTPase. $M_{\mathrm{f}}$ markers are shown on the right of the autoradiogram. The autoradiogram was obtained after exposure for 1 day. (a)

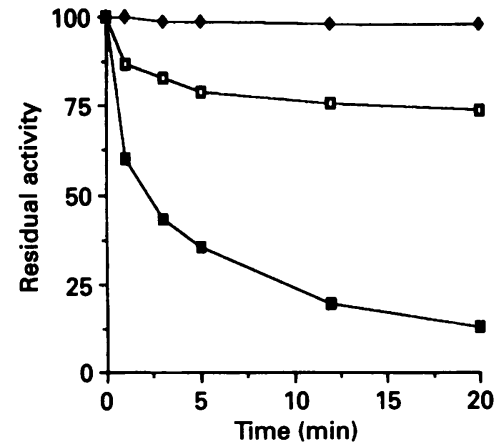

(b)

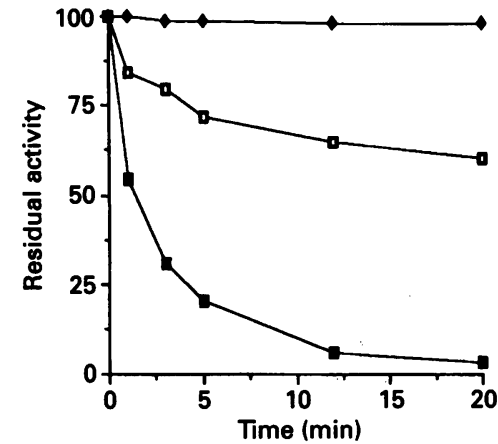

(c)

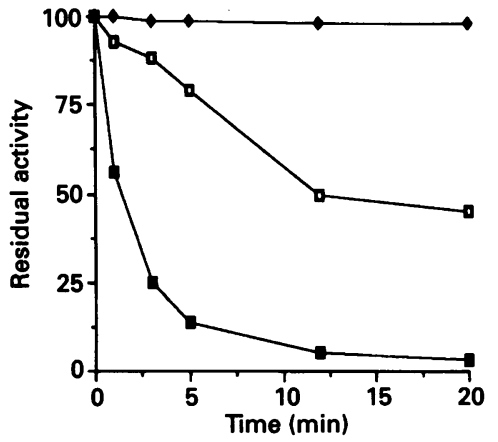

Figure 6 Inactivation of recombinant low- $M$, PTPases with DEP

(a) Non-mutated PTPase; (b) $\mathrm{His}^{66} \rightarrow \mathrm{Gln}$ mutant; (c) $\mathrm{His}^{72} \rightarrow \mathrm{Gln}$ mutant. Experiments were performed at pH 6.5 and $25^{\circ} \mathrm{C}$. $\diamond$. Without DEP; $\square$, with DEP; $\square$, with DEP and $\mathrm{P}_{\mathrm{i}}$. The initial DEP concentration was $2 \mathrm{mM}$; $P_{i}$ concentration was $30 \mathrm{mM}$.

difference between the kinetics for the $\mathrm{His}^{66}$ and $\mathrm{His}^{72}$ single mutants are observed. In the case of $\mathrm{His}^{86} \rightarrow \mathrm{Gln}$, the rate-limiting step is the E-P hydrolysis, as in the case of the non-mutated enzyme $\left(k_{+2} \gg k_{+3}\right.$, see Table 1). In contrast, for the $\mathrm{His}^{72} \rightarrow \mathrm{Gln}$ mutant, both $k_{+2}$ and $k_{+3}$ are involved in $k_{\text {cat. }}$ determination (the $k_{+3}$ value is only about half that of $k_{+2}$ ). In fact, according to the hydrolysis mechanism reported in Scheme $1, k_{\text {cat. }}=k_{+2} k_{+3} /$ $\left(k_{+2}+k_{+3}\right)$. Only when $k_{+2}>k_{+3}$ is the latter completely ratedetermining (see [17] and citations therein).

Phosphoenzyme covalent intermediate trapping experiments were used to gather further information on the enzymephosphorylation step in the $p$-nitrophenyl phosphate hydrolysis catalysed by $\mathrm{His}^{66} \rightarrow$ Gln and $\mathrm{His}^{72} \rightarrow$ Gln mutants. In the case of the $\mathrm{His}^{22} \rightarrow$ Gln mutant, we observed a strong reduction in the trapping efficiency (about 5-fold) with respect to the non-mutated enzyme, whereas for the $\mathrm{His}^{66} \rightarrow \mathrm{Gln}$ mutant, the trapping yield is very similar to that obtained with the non-mutated enzyme 
Type-2:

PTPase (Bovine)

AcP2 (Rat)

Bslow (Human)

PTPase (Porcine)

$$
\begin{aligned}
& 12 \quad{ }^{64} \\
& \text { CLGNICR. . . . RNHGISTAHKAR } \\
& \text { CLGNICR. . . . RNBGI HTAHKAR } \\
& \text { CLGNICR. . . . RHHGINTAHKAR }
\end{aligned}
$$

Type-1:

AcP1 (Rat)

Bfast (Human)

CLGNICR. . . . KKHGIHMQHIAR

CLGNICR. . . . KRHGI PMSHVAR

\section{Figure 7 Alignment of active-site regions of low- $M_{r}$ PTPases from various organisms}

The sequence data for rat $\mathrm{ACP} 1$ and $\mathrm{ACP2}$ and human erythrocyte Bfast and Bslow are from $[13,14]$, those for bovine liver PTPase are from [4], and those for porcine liver PTPase are from [29].

(Figure 5). Lane 3 reports for comparison the strongly increased trapping yield caused by the mutation $\mathrm{Cys}^{17} \rightarrow \mathrm{Ser}$, previously described by Cirri et al. [17]. Given that, in the experimental conditions used for E-P trapping, the yield of E-P depends mainly on the rate of denaturation relative to the rate of E-P dephosphorylation during the denaturation process, the trapping results presented in Figure 5 agree well with the hypothesis that $\mathrm{His}^{72}$ is involved in the step that leads to the formation of the E-P covalent complex. As Zhang and Van Etten [16] have suggested that an electrophile is involved in donating a proton to the transition state of the step that leads to the phosphorylation of the enzyme, our data suggest that $\mathrm{His}^{72}$ is involved in donating the proton.

\section{DEP chemical modification}

Given that the enzyme contains only two histidine residues, we performed site-directed chemical modification of histidine residues in the non-mutated and $\mathrm{His}^{66}$ and $\mathrm{His}^{72}$ mutants, using DEP. We performed these modification experiments at $\mathrm{pH} 6.5$ to minimize the possibility of reaction of DEP with side chains other than that of histidine, thereby rendering the reaction specific for histidine residues [28]. Figure 6 shows the inactivation behaviour of non-mutated, $\mathrm{His}^{66} \rightarrow \mathrm{Gln}$ and $\mathrm{His}^{72} \rightarrow \mathrm{Gln}$ mutated enzymes. It can be seen that the non-mutated recombinant enzyme is inactivated in a time-dependent manner by DEP, confirming the finding of Zhang et al. [19] on the bovine heart low- $M_{r}$ PTPase (Figure 6a). The enzyme was protected from inactivation by $P_{1}$ (a competitive inhibitor), indicating that the modification is directed to the active site. The mutants in $\mathrm{His}^{66}$ and $\mathrm{His}^{72}$ (Figures $6 \mathrm{~b}$ and $6 \mathrm{c}$ ), which retain only fractions of the activity of the non-mutated enzyme (see above), were completely inactivated by DEP; we want to emphasize that the enzyme was protected from inactivation in the presence of $P_{1}$. As each mutant contains a single histidine residue $\left(\mathrm{His}^{66}\right.$ or $\left.\mathrm{His}^{72}\right)$, these findings agree with the hypothesis that both $\mathrm{His}^{66}$ and $\mathrm{His}^{72}$ participate in the active site of the enzyme, even if neither $\mathrm{His}^{66}$ nor $\mathrm{His}^{72}$ is essential for enzyme activity. In fact, both the $\mathrm{His}^{66} \rightarrow$ Gln single mutant and the $\mathrm{His}^{72} \rightarrow$ Gln single mutant showed strongly reduced $k_{\text {cat. }}$ values relative to the non-mutated enzyme, but did not completely lose their activity. On the other hand, the His ${ }^{66}$ $\mathrm{His}^{22} \rightarrow$ Gln double mutant is completely inactive (see Table 1).

\section{Evolutionary conservation}

Figure 7 shows the sequence alignment of two regions (residues 12-18 and 64-75) of low- $M_{r}$ PTPases from various organisms
[29]. It can be noted that both $\mathrm{His}^{66}$ and $\mathrm{His}^{72}$ are conserved in all of the enzymes sequenced, including the type- 1 forms. We emphasize that type-1 and type- 2 isoenzymes are produced through an alternative splicing mechanism. The conservation of these residues in enzyme forms coded by different DNA stretches strongly reinforces the hypothesis that both histidine residues are necessary for achieving high catalytic activity. Figure 7 does not include other PTPases such as PTP 1B (a non-receptor-like enzyme) and CD45 (a receptor-like enzyme), because they share no general homology with the low- $M_{\mathrm{r}}$ PTPases. In fact, the homology is limited to the active site motif CXXXXXR present in all members of the PTPase family [17]. These enzymes show specific activities towards the substrate $p$-nitrophenyl phosphate that are lower [30] than that shared by the low- $M_{r}$ PTPases [13]. Taking into account that all PTPases have the same reaction mechanism [17], the lower specific activity found for the above mentioned PTPases may be attributable to the replacement of histidine with another amino acid able to act as a general base or acid catalyst, but with lower efficacy with respect to histidine.

We have previously demonstrated [17] that the sequence 12-18 of the bovine liver low- $M_{\mathrm{r}}$ PTPase is located at the active site, as the $\mathrm{Cys}^{17}-\mathrm{Arg}^{18}$ sequence represents part of the binding site of the phosphate moiety of substrates. In addition, Cys ${ }^{12}$ is the phosphate acceptor site in the formation of the phosphoenzyme covalent intermediate. Also, the sequence $12-18$ is strictly conserved in the known low- $M_{\mathrm{r}}$ PTPases. The participation of both $\mathrm{His}^{66}$ and $\mathrm{His}^{72}$ in the active site, as we have demonstrated above, suggests that the sequence $66-72$ is located near the sequence 12-17 in the natural enzyme fold, as both polypeptide stretches seem to be involved in substrate and inhibitor binding as well as in the catalytic events.

This work was supported in part by the CNR Target Project on Biotechnology and Bioinstrumentation and in part by the Ministero della Università e della Ricerca Scientifica e Tecnologica.

\section{REFERENCES}

1 Fischer, E. H., Charbonneau, H. and Tonks, N. K. (1991) Science 253, 401-406

2 Charbonneau, H. and Tonks, N. K. (1992) Annu. Rev. Cell. Biol. 8, 463-493

3 Pot, D. A. and Dixon, J. E. (1992) Biochim. Biophys. Acta 1136, 35-43

4 Camici, G., Manao, G., Cappugi, G., Modesti, A., Stefani, M. and Ramponi, G. (1989) J. Biol. Chem. 264, 2560-2567

5 Ramponi, G., Manao, G., Camici, G., Cappugi, G., Ruggiero, M. and Bottaro, D. P. (1989) FEBS Lett. 250, 469-473

6 Zhang, Z. Y. and Van Etten, R. L. (1990) Arch. Biochem. Biophys. 282, 39-49

7 Chernoff, J. and Lee, H. C. (1985) Arch. Biochem. Biophys. 240, 135-145

8 Boivin, P. and Galand, C. (1986) Biochem. Biophys. Res. Commun. 134, 557-564

9 Waheed, A., Laidler, P. M., Wo, Y. Y. P. and Van Etten, R. L. (1988) Biochemistry 27, 4265-4273

10 Shekels, L. L., Smith, A. J., Van Etten, R. L. and Bernlohr, D. A. (1992) Protein Sci. 1. $710-721$

11 Raugei, G., Marzocchini, R., Modesti, A., Ratti, G., Cappugi, G., Camici, G., Manao, G. and Ramponi, G. (1991) Biochem. Int. 23, 317-326

12 Ramponi, G., Ruggiero, M., Raugei, G., Berti, A., Modesti, A., Degl'Innocenti, D. Magnelli, L., Pazzagli, C., Chiarugi, V. P. and Camici, G. (1992) Int. J. Cancer 51, 652-656

13 Manao, G., Pazzagli, L., Cirri, P., Caselli, A., Camici, G., Cappugi, G., Saeed, A. and Ramponi, G. (1992) J. Protein Chem. 11, 333-345

14 Dissing, J., Johnsen, A. H. and Sensabaugh, G. F. (1991) J. Biol. Chem. 266, 20619-20625

15 Wo, Y. Y. P., McCormack, A. L., Shabanowitz, J., Hunt, D. F., Davis, J. P., Mitchell, G. L. and Van Etten, R. L. (1992) J. Biol. Chem. 267, 10856-10865

16 Zhang, Z. Y. and Van Etten, R. L. (1991) Biochemistry 30, 8954-8959

17 Cirri, P., Chiarugi, P., Camici, G., Mana0, G., Raugei, G., Cappugi, G. and Ramponi, G. (1993) Eur. J. Biochem. 214, 647-657

18 Zhang, Z. Y. and Van Etten, R. L. (1991) J. Biol. Chem. 266, 1516-1525

19 Zhang, Z. Y., Davis, J. P. and Van Etten, R. L. (1992) Biochemistry 31, 1701-1711

20 Wo, Y. Y. P., Zhou, M. M., Stevis, P., Davis, J. P., Zhang, Z. Y. and Van Etten, R. L. (1992) Biochemistry 31, 1712-1721 
21 Chiarugi, P., Marzocchini, R., Raugei, G., Pazzagli, C., Berti, A., Camici, A., Manao, G., Cappugi, G. and Ramponi, G. (1992) FEBS Lett. 310, 9-12

22 Baginski, E. S., Foa, P. P. and Zak, B. (1967) Clin. Chim. Acta 15, 155-158

23 Lineweaver, H. and Burk, D. (1934) J. Am. Chem. Soc. 56, 658-666

24 Mullis, K., Faloona, F., Scharf, S., Saiki, R., Horn, G. and Elrich, H. (1986) Cold Spring Harbor Symp. Quant. Biol. 51, 263-273

25 Guan, K. L. and Dixon, J. E. (1991) J. Biol. Chem. 266, 17026-17030

26 Pot, D. A., Woodford, T. A., Remboutsika, E., Haun, R. S. and Dixon, J. E. (1991) J. Biol. Chem. 266, 19688-19696
27 Cirri, P., Chiarugi, P., Camici, G., Manao, G., Pazzagli, L., Caselli, A., Barghini, I., Cappugi, G., Raugei, G. and Ramponi, G. (1993) Biochim. Biophys. Acta 1161, 216-222

28 Muhlrad, A., Hegyi, G. and Horanyi, M. (1969) Biochim. Biophys. Acta 181, 184-190

29 Caselli, A., Pazzagli, L., Paoli, P., Manao, G., Camici, G., Cappugi, G. and Ramponi, G. (1994) J. Protein Chem., in the press

30 Zhao, Z., Bouchard, P., Diltz, C. D., Shen, S. H. and Fischer, E. H. (1993) J. Biol. Chem. 268, 2816-2820

Received 12 July 1993/1 November 1993; accepted 11 November 1993 